\title{
e-cadernos CES
}

\section{Loucura, sagrado e poesia. A obra autobiográfica de Janet Frame à luz de Julia Kristeva}

\section{Ana Pires Quintais}

\section{(2) OpenEdition \\ Journals}

\section{Edição electrónica}

URL: http://journals.openedition.org/eces/919

DOI: $10.4000 /$ eces.919

ISSN: 1647-0737

\section{Editora}

Centro de Estudos Sociais da Universidade de Coimbra

Refêrencia eletrónica

Ana Pires Quintais, «Loucura, sagrado e poesia. A obra autobiográfica de Janet Frame à luz de Julia Kristeva », e-cadernos CES [Online], 14 | 2011, colocado online no dia 01 dezembro 2011, consultado a 01 maio 2019. URL : http://journals.openedition.org/eces/919 ; DOI : 10.4000/eces.919 


\section{LOUCURA, SAGRADO E POESIA ${ }^{1}$}

\section{A OBRA AUTOBIOGRÁFICA dE JANET Frame À LUZ de JULIA KRISTEVA}

\section{ANA PIRES QUINTAIS}

FACULDADE DE LETRAS DA UNIVERSIDADE DE COIMBRA

Centro de Estudos Sociais, Universidade de Coimbra

Resumo: Pretende-se com este texto pensar a obra autobiográfica de Janet Frame tendo em conta o campo teórico enunciado por Julia Kristeva, nomeadamente o conceito de abjeto que a autora propõe. Ao mesmo tempo procura-se analisar o impacto de um contexto colonial e patriarcal como o da Nova-Zelândia em meados dos anos 50 na vida de uma mulher que, desde muito cedo, mostrou sinais de revolta face a um ambiente e a uma sociedade hegemónicos.

Palavras-chave: Janet Frame; Julia Kristeva; abjeto; autobiografia; feminismo.

Come in, you naughty bird, the rain is pouring down, what will your mother say if you stay there and drown?

Frame (2010: 66)

\section{INTRODUÇÃO}

Janet Frame (1924-2003) foi uma das escritoras mais bem-sucedidas da Nova Zelândia, tendo escrito desde romances a contos, passando pela poesia, ensaios críticos e livros para a infância. Ganhou mais de trinta prémios e distinções ao longo da sua vida e, em 1990, a(s) sua(s) autobiografia(s) foi/foram transposta(s) para o cinema pela mão de Jane Campion, que prefaciou a recente edição conjunta dos três volumes autobiográficos, ${ }^{2}$

\footnotetext{
1 Tradução livre de "Madness, Holiness, Poetry", termos aos quais Elizabeth Grosz se refere como constituindo uma espécie de "trindade revolucionária" fundada por Julia Kristeva (Grosz, 1989).

${ }^{2}$ Originalmente os três volumes da autobiografia de Janet Frame surgiram separadamente: To the Is-Land publicado pela primeira vez em 1982, An Angel at My Table em 1984 e no ano seguinte The Envoy from Mirror City encerra a trilogia autobiográfica.
} 
com o título An Angel at My Table (2010), da Virago Press. Embora a receção da sua autobiografia pelo público e críticos neozelandeses tenha sido positiva, a crítica internacional não ficou impressionada com aquilo que apelidou de "[...] straight reportage [...] [and not] being particularly complex and challenging at all." (Merli e Torney, 1997: 66). De facto, numa conferência realizada em 1992, pela Associação de Literatura Neozelandesa, a trilogia autobiográfica de Frame foi caracterizada como sendo um registo acessível, bem-humorado, com um pensamento provocador mas não ameaçador (ibidem).

Os objetivos deste texto são justamente contrariar esta caracterização redutora e aparentemente condescendente que a maioria dos críticos tem feito à obra autobiográfica de Janet Frame. Utilizando as linhas teóricas de Julia Kristeva e especialmente o seu conceito de abjeto, procura-se pensar a trilogia autobiográfica de Frame como uma produção literária de uma speaking subject ${ }^{3}$ (Kristeva, 1982), que mostrou na sua escrita o enorme sofrimento a que foi sujeita durante a maior parte da sua vida.

\section{NO PRINCÍPIO}

"In the beginning was the deed" escreve Freud na sua obra Totem and Taboo (1919: 268), ${ }^{4}$ referindo-se segundo Kristeva (1982), a um "início" anterior à linguagem. Através do registo de três "lugares diferentes", Janet Frame aparenta estar consciente da subjetividade inerente a todos os seres humanos, seres em processo ${ }^{5}$, originados num espaço de profunda escuridão. A escritora inicia a sua autobiografia com uma frase que parece enunciar esse processo de constituição da subjetividade humana: "From the first place of liquid darkness, within the second place of air and light, I set down the following record with its mixture of fact and truths and memories of truths and its direction always toward the Third Place, where the starting point is myth." (Frame, 2010: 3).

Podemos talvez pensar neste lugar original como pertencendo à noção de chora que Kristeva (1982) vai buscar a Platão. Kristeva defende que cada pessoa, antes de desenvolver fronteiras e limites definidos da sua identidade pessoal, se encontra imersa no chora que, mais do que um espaço ou recetáculo, é o lugar (materno) onde o bebé vivencia múltiplas forças ou drives (por exemplo instintos, emoções) e que fazem parte do semiótico. ${ }^{6}$ É com o advento da linguagem ligada ao simbólico que a criança acede a um

\footnotetext{
${ }^{3}$ Para Kristeva a ideia de um speaking subject relaciona-se com práticas significantes. Como a própria explica: "Speaking subjects are human beings who signify and are constituted through their signifying practices." (apud McAfee, 2004: 9).

${ }^{4}$ Totem und Tabu: Einige Übereinstimmungen im Seelenleben der Wilden und der Neurotiker (1913) no original.

5 "Le sujet en procès" formulado por Kristeva (1982) pode ser traduzido por sujeito em processo ou em julgamento, segundo McAfee (2004).

"O "semiótico" é um conceito distinto de "semiótica", este último implicando o estudo dos signos. A noção de
} 
"segundo lugar" no qual se sujeita a outras forças, desta feita, àquelas que podemos designar como culturais, históricas e sociais. Assim, é através da aquisição da linguagem que a criança entra no reino do simbólico no qual vai adquirir as regras e normas linguísticas para poder comunicar com os outros. Contudo, não abandona nunca o semiótico, que acompanha constantemente o simbólico em todas as suas comunicações. Segundo McAfee (2004) e citando Kristeva, a linguagem pode ser encarada como um sistema discursivo ou significante no qual "the speaking subject makes and unmakes himself" (14). Esta construção (e desconstrução) pela linguagem encontra-se patente na autobiografia de Janet Frame desde o início. O título do primeiro volume da sua autobiografia To the Is-Land parte da resistência, por parte de Frame, em aceitar a norma linguística do $s$ mudo na palavra island:

That year I discovered the word Island, which in spite of all teaching I insisted on calling Is-Land. [...] 'I read a story, To the Is-Land, about some children going to an Is-Land.' 'It's I-Land', Myrtle corrected. 'It's not', I said. 'It's Is-Land. It says', I spelled the letters, 'I-s-I-a-n-d. Is-land.' 'It's a silent letter', Myrtle said. 'Like knee.' In the end, reluctantly, I had to accept the ruling, although within myself I still thought of it as the Is-Land. (Frame, 2010: 35)

Podemos encontrar neste excerto as dificuldades de Janet na interiorização das normas linguísticas, que parecem ser claras, "limpas" e ordenadas, representativas de uma sociedade também ela ordenada e clara (Kristeva, 1982), na qual não parece haver espaço para o lado rebelde de Janet ou para a sua linguagem desordenada e por si "construída". Escreve Frame: "I wrote in my diary, 'Dear Mr. Ardenue, They think l'm going to be a schoolteacher, but I'm going to be a poet." (2010: 157). A escolha da poesia não é feita por acaso. É talvez a única maneira disponível para Janet poder expressar o seu semiótico dentro daquilo que a sociedade permite. Como refere McAfee, citando Kristeva no original: "No living, speaking being is immune from semiotic disruptions. Moreover, no speaking being could function sanely unless it expresses the semiotic in some way." (2004: 39). Em Revolution in Poetic Language (1984), ${ }^{7}$ cuja tese principal reside na produção de uma "revolução na linguagem poética" analisada por Kristeva através dos trabalhos literários de escritores avant-garde (McAfee, 2004), a autora afirma que a revolução na linguagem poética advém precisamente dos elementos gerados pelo chora,

semiótico na teoria de Kristeva indica um modo que é extraverbal, e através do qual a energia corporal e os afetos tentam alcançar a linguagem. As expressões do semiótico podem ser encontradas mais facilmente na arte: na música, dança e poesia (McAfee, 2004).

${ }^{7}$ A obra La révolution du langage poétique de Julia Kristeva foi publicada em 1974, tendo sido mais tarde traduzida para esta versão inglesa que não contém a totalidade da obra original (McAfee, 2004). 
defendendo uma revolta que não está limitada à linguagem artística mas presente em todas as formas pelas quais os seres humanos tentam expressar-se.

\section{PUREZA E PERIgo}

Ao longo da autobiografia de Janet Frame apercebemo-nos dos constrangimentos sociais que a todo o momento lhe parecem ser impostos, seja no que diz respeito ao seu corpo, seja ao nível do pensamento. Sobre aquilo que os outros exteriorizam acerca das suas opiniões pessoais - ou até sobre o seu próprio cabelo - escreve Janet:

'Jean's so original', the teacher said one day, causing me once again to feel trapped by the opinion of others. I did not think myself as original: I merely said what I thought. [...] I came to accept the difference, although in our world of school, to be different was to be peculiar, a little 'mad' [...] my awareness of it helped to efface my growing consciousness of my body, the now-too-tight tunic often dirtied with cow muck and byre mud, the cobble-mended stockings coarse and thick, my frizzy tangle of red hair, which seemed to alarm everyone the way it naturally grew up instead of down, causing people to keep asking, 'Why don't you straighten it? Why don't you comb it flat, make it stay flat, put oil on it or something; no one else has hair like yours.' And no one had [...] (Frame, 2010: 129-131)

Para Merli e Torney (1997), o corpo encontra-se omnipresente na trilogia autobiográfica de Frame, um corpo que balança nos limites do "puro e do perigoso", para usar as palavras da antropóloga britânica Mary Douglas que dão título à sua obra de 1966 (edição portuguesa: 1991): "Her body registers the trilogy's central concern, the struggle between the socialized and the 'dangerous', that which cannot comfortably be contained within the boundaries of either New Zealand society or realist narrative." (Merli e Torney, 1997: 64). E o corpo de Janet parece assim desafiar as normas sociais do corpo limpo e apropriado de que fala Kristeva (1982), aludindo aos rituais que a sociedade e a religião formularam para fazer face à ameaça do abjeto. O estado de abjeção é, de acordo com Kristeva (ibidem), o processo fundamental do sujeito, uma vez que cria as fronteiras que definem a identidade pessoal. Enquanto Lacan argumenta que a emergência da subjetividade ocorre quando, entre os seis e os 18 meses, a criança vislumbra a sua imagem no espelho, Kristeva embora concordando que, nesta chamada "fase do espelho" existe o estabelecimento de um sentido de unidade por parte do sujeito, também defende que os limites entre o eu e o outro começam a ser definidos mais cedo. 
A autora explica em Powers of Horror, ${ }^{8}$ onde descreve o processo de abjeção - vital para a formação da subjetividade -, que as fronteiras começam a ser delineadas através do abjeto, pelo qual o bebé se livra (violentamente) daquilo que parece fazer parte de si. Comenta McAfee:

The abject is what one spits out, rejects, almost violently excludes from oneself: sour milk, excrement, even a mother's engulfing embrace. What is abjected is radically excluded but never banished altogether. It hovers at the periphery of one's existence, constantly challenging one's own tenuous borders of selfhood. What makes something abject and not simply repressed is that it does not entirely disappear from consciousness. It remains as both an unconscious and a conscious threat to one's own clean and proper self. The abject is what does not respect boundaries. It beseeches and pulverizes the subject. (2004: 46).

O abjeto não respeita limites, tal como a perceção por parte da sociedade neozelandesa do corpo de Janet, um corpo que foge às normas. Sobre este corpo escrevem Merli e Torney: "Her body is awkward and dowdy in appearance, but nevertheless possesses wrists that can snap bracelets and hair that refuses to be disciplined into a fashionable meekness." (1997: 64). Desta forma, parece haver uma resistência por parte de Janet a ceder aos constrangimentos que a sociedade lhe tenta impor, colocando-a numa espécie de zona fronteiriça e marginalizando-a porque perturba a ordem social. Para Kristeva, o abjeto para além de fazer parte da cultura é, em simultâneo, gerador de margens e fronteiras. Assim, aquilo que causa abjeção é o que transtorna o sistema, o que parece não obedecer à regra: "It is thus not lack of cleanliness or health that causes abjection but what disturbs identity, system, order. What does not respect borders, positions, rules. The in-between, the ambiguous, the composite." (1982: 4).

De acordo com Merli e Torney (1997), a autobiografia de Frame levanta questões sobre se a sobrevivência de um corpo não-normativo numa sociedade conservadora é possível sem a destruição das energias criativas desse mesmo corpo. Mary Douglas (1991) defende que os indivíduos que não se enquadram nas categorias construídas socialmente, nomeadamente no asseio do corpo ou num corpo normativo, são percecionados como perigosos porque desafiam as leis da ordem, perturbando um sistema que controla e contém, e vulneráveis porque se encontram fora desse sistema. Kristeva (1982) usa o ensaio de Douglas para se referir à sujidade e à conspurcação que as sociedades excluem, promovendo uma lógica de higienização e, em última análise,

\footnotetext{
${ }^{8}$ Pouvoirs de l'horreur. Essai sur l'abjection (1980) no original.
} 
uma linha divisória que funda o self and clean de cada grupo social e de cada indivíduo através de ritos de purificação. Para a autora, certas sociedades e religiões baniram determinados alimentos e práticas porque ameaçam a identidade do self e/ou da ordem social. Comenta Kristeva: "Defilement, by means of the rituals that consecrate it, is perhaps, for a social aggregate, only one of the possible foundings of abjection bordering the frail identity of the speaking being." (1982: 67). De acordo com esta autora, o abjeto pode assumir várias formas consoante os diversos sistemas simbólicos de cada sociedade. Estas formas ou codificações podem variar entre as categorias de "sujidade", "comida" e "tabu". Na obra autobiográfica de Janet Frame encontramos constantemente todas estas referências interligadas a corpos que perturbam as normas de contenção e da ordem. Corpos que vazam, que cheiram, que suam, que se contorcem, corpos que são insaciáveis e devoradores, mas também comidos e devorados por doenças, corpos que o deixam de ser mas que ainda existem - numa transitoriedade patente na figura do cadáver.

\section{CORPOS QUE VAZAM E SE CONTORCEM}

O vómito e os sentimentos de aversão e de repulsa são exemplos de mecanismos de proteção do indivíduo face ao abjeto, à visualização de dejetos corporais, aos excrementos, à sujidade, e a determinados alimentos. A este propósito escreve Kristeva:

Food loathing is perhaps the most elementary and most archaic form of abjection. When the eyes see or the lips touch that skin on the surface of milk - harmless, thin as a sheet of cigarette paper, pitiful as a nail paring - I experience a gagging sensation and, still farther down, spasms in the stomach, the belly; and all the organs shrivel up the body, provoke tears and bile, increase heartbeat, cause forehead and hands to perspire. Along with sight-clouding dizziness, nausea makes me balk at that milk cream, separates me from the mother and father who proffer it. "I" want none of that element, sign of their desire; "I" do not want to listen, "I" do not assimilate it, "l" expel it. But since the food is not an "other" for "me," who am only in their desire, I expel myself, I spit myself out, I abject myself within the same motion through which "I" claim to establish myself. (1982: 3-4).

Para Kristeva, os "objetos" que caem dos orifícios do corpo e que "poluem" o mundo podem ser divididos em duas categorias: a categoria dos excrementos e aquela que diz respeito ao sangue da menstruação:

Neither tears nor sperm, for instance, although they belong to borders of the body, have any polluting value. Excrement and its equivalents (decay, infection, disease, 
corpse, etc.) stand for the danger to identity that comes from without: the ego threatened by the non-ego, society threatened by its outside, life by death. (1982: 71).

O sangue é associado ao feminino, à fertilidade, mas também a um perigo emitido pelo que existe dentro da identidade e uma ameaça ao relacionamento entre sexos diferentes. Janet luta para conseguir conter os constantes "vazamentos" do seu corpo, seja através dos panos volumosos destinados a conter o sangue menstrual ou através de uma gaveta contentora onde guarda os toalhetes sanitários usados, evitando a incineradora da sua escola que poderia purificar e conter por meio do fogo aquilo que ultrapassa as fronteiras do corpo:

I was overawed, too, by the lavatories. Near the wash-basin was an incinerator with a sign, Deposit Used Sanitary Towels Here. One had to walk, with soiled sanitary towel in hand for all to see, from the lavatory, across the tilled echoing floor, to the incinerator at the far end of the room. In my two years at Training College I carried my soiled sanitary towels home to Number Four Garden Terrace [...] My few clothes shared the dressing-table drawer with used sanitary towels waiting to be thrown in the cemetery [...] (Frame, 2010: 182).

Com a escolha da gaveta no seu quarto e o cemitério ao fundo da rua, Janet prefere um modo muito próprio de sacralizar aquilo que poderia contaminar o mundo. Uma gaveta contentora, repetindo um hábito familiar, ${ }^{9}$ e um terreno sagrado dos mortos. Morte e fertilidade compõem assim uma associação que podemos encontrar amiúde na trilogia autobiográfica de Frame, bastando pegar na recordação de Janet e dos seus períodos menstruais enquanto jaz no chão do quarto em Andorra depois de ter abortado (Merli e Torney, 1997).

Tiques nervosos impossíveis de controlar e corpos sujeitos a ataques incontroláveis (a epilepsia do irmão Bruddie) fazem parte da perigosidade em que Janet e a sua família aparentam estar imersos. Uma perigosidade que se opõe à pureza, à higiene que a sociedade ordena: "Anyone observing me during those days would have seen an anxious child full of twitches and tics, standing alone in the playground at school [...]" (Frame, 2010: 43). Estes corpos que extravasam são, assim, corpos sujos, indisciplinados, que necessitam de ser contidos quer através da medicação ("Bruddie became stupefied by drugs" [ibidem: 42]), quer através de rótulos sociais:

\footnotetext{
${ }^{9}$ Ver Frame (2010: 6-7).
} 
[...] a freckle-faced, frizzy-haired little girl who was somehow 'dirty' because the lady doctor chose her with the other known 'dirty and poor' children for a special examination in that narrow room next to the teacher's room. I had tide marks of dirt behind my knees and on my inner arms, and when I saw them, I felt a wave of shock to know they were there when I had been sure I had washed thoroughly (Frame, 2010: 43-44)

Ou ainda através de dolorosas práticas psiquiátricas - choques elétricos e leucotomias ou lobotomias:

It is little wonder that I value writing as a way of life when it actually saved my life. My mother had been persuaded to sign permission for me undergo a leucotomy; [...] I listened also with a feeling that my erasure was being completed when the ward sister [...] painted her picture of how I would be when it was 'all over'. We had one patient who was here for years until she had a leucotomy. And now she's selling hats in a hat shop. [...] Wouldn't you like to be normal? (ibidem: 263-264).

\section{CoRPOS DEVORADORES E DEVORADOS}

Para Merli e Torney (1997) o próprio nascimento de Janet é representativo da sua vontade de não sucumbir, nem que seja pela devoração do seu gémeo: "I was known as 'the baby who was always hungry'. I had a twin, which did not develop beyond a few weeks." (Frame, 2010: 7). Segundo as autoras, desde o início da sua autobiografia Janet parece expor a necessidade de, em plena infância, ter que ser devoradora e possuir uma força impiedosa para sobreviver: "Thou wast not born for death, Immortal Bird!/ No hungry generations tread thee down;/ The voice I hear this passing night was heard/ In ancient days by Emperor and clown [...]" (ibidem: 113). Janet diz à sua tia Isy que é vegetariana e que por essa razão não necessitará de comer muito, preferindo inclusive fazer as suas refeições no quarto. Esta mentira, causada pela ansiedade em se tornar "a hóspede perfeita", obriga uma Janet arrependida e esfomeada a atacar secretamente os restos de comida deixados pela tia: "l'd grab delicious scraps of boiled corned beef, set aside as being 'too stringy', from Aunty Isy's plate among the pile of dirty dishes." (ibidem: 182). $O$ tema da devoração é uma constante na autobiografia de Frame e a sua ligação com a sobrevivência parece ser central no episódio em que Janet e a irmã Isabel invadem a sala onde a tia Isy guarda os troféus (caixas de chocolates) que ganhou enquanto dançarina. É nesta mesma sala que a tia também guarda roupinhas de bebé, compradas e tricotadas para as crianças que nunca chegaram a viver para além de poucas semanas: "We knew that Dad's sisters Polly and Isy had stillborn babies or those who did not 
survive beyond a few days or weeks, $[\ldots]$ and even as children we had sensed a kind of hunger in Aunty Polly's and Aunty Isy's feeling toward us [...]" (ibidem: 200). E é durante o exame às roupas infantis, novas e nunca usadas, que Janet e a irmã comem os chocolates da tia, um por um, estabelecendo a ligação entre a insaciabilidade do corpo e a sua deterioração até à morte, e que Janet narra, aludindo à devoração dos fetos e ao triunfo sobre o corpo moribundo do tio George:

During our stay at Garden Terrace we ate gradually all the chocolates from all the boxes around the picture rail, returning the boxes when we had finished, and each time we sneaked into the darkened front room we remembered the new baby clothes but did not look at them again, and as we ate our fill, we wondered about Aunty Isy and how her life had been and I told Isabel about Uncle George in bed, and the lanoline, and when we scattered the empty paper cases into the empty box we both felt distaste at what we were doing, eating Aunty Isy's cherished souvenirs; eating, eating. The frill around the paper cases was like the frill, withered at the edges, of some small shells you prise open on the beach, to find a small dead heap with a black dead eye lying inside. (Frame, 2010: 200-201).

A decadência e a lenta desintegração do corpo também fazem parte dos temas presentes na trilogia autobiográfica de Janet Frame. Na verdade, Janet inicia a sua autobiografia com a enumeração dos seus familiares (mortos) e a tendência da parte da família da mãe para originar gémeos (mortos). Fala-nos também das ninhadas de gatos e cachorros afogados (o mesmo acontecerá às irmãs Isabel e Myrtle) e de uma série de corpos "defeituosos" (por exemplo os corações "defeituosos" de Myrtle e de Isabel, a epilepsia de Bruddie) e comidos por doenças (por exemplo o cancro da garganta da tia paterna Maggie, o cancro do tio George: "I noted the grey pallor of his face with its softlooking skin, like dead skin, and I wondered what dreadful sight was concealed beneath the bedclothes." [ibidem: 178], e a paralisia de Mrs. O.) ou mutilados (por exemplo a avó paterna cuja diabetes levou à amputação das duas pernas, a castração do bezerro Bluey).

\section{CORPO OU CADÁVER}

De acordo com Kristeva, os cadáveres também despoletam a abjeção. Refere a autora: "If dung signifies the other side of the border, the place where I am not and which permits me to be, the corpse, the most sickening of wastes, is a border that has encroached upon everything. It is no longer I who expel, 'I' is expelled” (1982: 3-4). O cadáver simboliza a 
rutura da fronteira entre vida e morte, fazendo com que aqueles que o presenciam se possam sentir contaminados, apercebendo-se da fragilidade da vida humana:

Deprived of world, therefore, I fall in a faint. In that compelling, raw, insolent thing in the morgue's full sunlight, in that thing that no longer matches and therefore no longer signifies anything, I behold the breaking down of a world that has erased its borders: fainting away (Kristeva, 1982: 4).

O cadáver infeta de forma direta a vida e ameaça as fronteiras do sujeito. É abjeto. E deste abjeto e desta infeção foge Janet durante todos os momentos em que negou o confronto com os cadáveres da sua família:

Not long after then, Grandma died, and when she was lying in the front room, Mother came to Myrtle and Bruddie and me, saying, "Would you like to see Grandma?' The others said yes and went solemny to look at the dead, while I hung back, afraid and always to regret that I did not see Grandma dead. When Myrtle came out of the room, I could see in her face the power of having looked at the dead. [...] And some years later when Myrtle herself was lying dead in her coffin in the front room at Oamaru and Mother asked me, 'Do you want to see Myrtle?' I, never learning, still fearful, refused to look on the face of the dead. (Frame, 2010: 23)

\section{MÃE ABJETO}

A primeira coisa que a criança necessita de fazer para alcançar a sua subjetividade é traçar os limites entre si e o corpo da mãe. Estes limites só poderão ser alcançados através do processo de abjeção que lhe permite literalmente "cuspir-se" da mãe. Desta forma: "The child is in a double-bind: a longing for narcissistic union with its first love and a need to renounce this union in order to become a subject. It must renounce a part of itself - insofar as it is still one with the mother - in order to become a self." (McAfee, 2004: 48). Ao contrário da noção de repressão freudiana, Kristeva defende que o processo de abjeção estará sempre presente na vida do sujeito:

But what the child abjects is not gone once and for all. The abject continues to haunt the subject's consciousness, remaining on the periphery of awareness. The subject finds the abject both repellant and seductive and thus his or her borders of self are, paradoxically, continuously threatened and maintained. They are threatened because the abject is alluring enough to crumble the borders of self; they are 
maintained because the fear of such a collapse keeps the subject vigilant. (McAfee, 2004: 49-50)

O abjeto que acompanha constantemente o indivíduo encontra-se também presente na mãe. De acordo com Kristeva (1982), há um medo e uma sedução constantes em cair ou voltar ao corpo materno, na perda da própria identidade. $\mathrm{Na}$ autobiografia de Janet Frame existe uma contínua distinção entre a sua identidade e a da mãe através das várias escolhas que Janet realiza e da vontade que mostra de não cair nesse mundo/corpo materno, quer recusando ler os poetas que associa à mãe, quer negando o tipo de existência a que a sua mãe se votou, revoltando-se contra a suposta servidão que a mãe demonstra, a mesma servidão que a sociedade oferece à mulher:

Aware now that Mother had turned increasingly to poetry for shelter, as I was doing, I, with an unfeelingness based on misery of feeling, challenged the worth of some of her beloved poets, aware that my criticism left her flushed and unhappy while I felt a savage joy at her distress. I had begun to hate her habit of waiting hand and foot, martyrlike, upon her family. When I was eager to do things for myself, Mother was always there, anxious to serve. (Frame, 2010: 153-154)

Segundo Kristeva, faz parte da patologia do abjeto transformar o fantasma daquilo que é abjeto num objeto odiado: "a dread object, an object of hate." (McAfee, 2004: 53). O corpo materno devorado pela pobreza da vida a que voluntariamente se dispôs é um corpo em contraponto com o próprio corpo de Janet que, rebelde, não é passível de ser dominado ou disciplinado:

Mother in a constant state of family immersion even to the material evidence of the wet patch in front of her dress where she leaned over the sink, washing dishes, or over the cooper and washtub, or, kneeling, wiped the floor with oddly shaped floorcloths - old pyjama legs, arms and tails of worn shirts - or, to keep at bay the headache and tiredness of the hot summer, the vinegar-soaked rag she wrapped around her forehead: an immersion so deep that it achieved the opposite effect of making her seem to be seldom at home, in the present tense, or like an unreal person with her real self washed away. (Frame, 2010: 5)

A compra que Janet efetua de uma dentadura falsa serve também para se distanciar da figura materna que, desdentada, cede à normalização de um país colonizado que perceciona o cuidado da dentição natural como uma perda de tempo. Janet compra uns 
dentes novos para assim recusar ser mordida e ver o seu self washed away, como aconteceu com a mãe. Ao mesmo tempo são vários os momentos em que nos apercebemos do tentador regresso ao chora materno, esse reino de plenitude, no qual todas as necessidades são satisfeitas, onde não existem ordens, dilemas ou escolhas que o sujeito separado do Outro tem de realizar desde o momento em que acede ao simbólico e à socialização. Observamos esses momentos sempre que Janet se refugia nos vários asilos para descansar e não ser obrigada a decidir da sua vida. Apercebemonos também desse desejo quando acarinha a ideia de ser esquizofrénica e, afinal, ter que ser cuidada. Durante muito tempo acalenta a ideia de ter um problema mental ou físico real que the permita ser comparada aos poetas e escritores que admira, e que the possibilite uma espécie de "parêntese paradisíaco": ${ }^{10}$

I longed to be struck with paralysis so that I might lie in bed all day or sit all day in a wheelchair, writing stories and poems [...] (Frame, 2010: 91)

My dream of being a poet, a real poet, was nearer to being realized. There was still the question of a disability - Coleridge and Francis Thompson and Edgar Allan Poe had their addiction to opium, Pope his lameness, Cowper his depression, John Claire his insanity, the Brontes their tuberculosis as well the disablement of their life about them [...] (Frame, 2010: 157)

Após saber que o diagnóstico de esquizofrenia tinha sido um erro e que nunca sofrera de tal patologia, Janet sente-se "desagasalhada", sem as roupagens da doença mental que a levou a passar quase onze anos em instituições psiquiátricas, e que associara com o génio literário:

I had never suffered from schizophrenia, he said. [...] I myself had suddenly been stripped of a garment I had worn for twelve or thirteen years - my schizofrenia. I remembered how wonderingly, fearfully I had tried to pronounce the word when I first learned of the diagnosis, how I had [...] accepted it, how in the midst of the agony and terror of the acceptance I found the unexpected warmth, comfort, protection: how I had longed to be rid of the opinion but was unwilling to part with it. And even when I did not wear it openly I always had it by for emergency, to put on quickly, for shelter from the cruel world. And now it was gone [...] I could never again turn to it for help. (Frame, 2010: 447)

\footnotetext{
${ }^{10}$ Herberto Helder (2001: 97-98).
} 
Contudo, Janet encontra na figura do Dr. Cawley o psiquiatra que a ajuda a encontrar o seu self. Sugerindo-Ihe que escreva sobre as suas experiências nas várias instituições mentais onde esteve internada possibilita à escritora, porventura, uma forma catártica de resolver grande parte dos conflitos que a perseguem desde muito cedo, e que foram realçados pela contínua institucionalização. É deste modo que a escrita e a literatura têm para Janet Frame um duplo sentido: se de alguma maneira a conduziram a anos de terror também é certo que lhe salvaram a vida, como admite na sua autobiografia.

\section{O PREÇO DA REVOLTA OU ALGUMAS NOTAS FINAIS}

"Happiness exists only at the price of a revolt." (Kristeva, 2000 apud McAfee, 2004: 113). Para Julia Kristeva, independentemente da diferença entre sociedades e religiões e das suas proibições comportamentais, existe sempre, através da ritualização dos dejetos e sua contaminação, uma noção muito forte de diferença entre os sexos, na qual os direitos do homem prevalecem sobre os direitos da mulher. E porque vivemos numa sociedade que, segundo a autora, parece anestesiada e cada vez mais longe do seu lado semiótico, faz todo o sentido que se clame por uma revolta que é afinal de ordem cultural e psicológica. Janet Frame foi uma mulher que não se deixou "anestesiar" e resistiu às imposições de uma sociedade patriarcal que num determinado momento a desejou a vender chapéus: "We consume and therefore we need not have real aspirations of our own" (McAfee, 2004: 108). Frame sujeitou-se a toda uma espécie de sofrimento inominável, unicamente por ousar transcender o estatuto que uma mulher deveria ter na Nova Zelândia, em meados dos anos 50. A resistência de Janet Frame é representativa da revolta psicológica de Kristeva (2000), "revolt against identity, homogenization, the spectacle, and the law" (apud McAfee, 2004: 118).

Tendo conseguido por fim ter êxito como escritora reconhecida, Frame teve no entanto, que optar pela sua mente, pela criação da sua arte, num mundo (ainda) dividido pelos pólos corpo e mente, deixando de lado qualquer hipótese de uma concretização mais física, associada à constituição de família. A "terceira via" para um feminismo de século XXI de que fala Kristeva (ibidem), e que Janet não encontrou, é precisamente aquela em que uma mulher se possa sentir livre para ter filhos e criar cultura: "to be of the body and mind" (ibidem: 76). No final da autobiografia deparamo-nos com os frutos que a "revolta" individual trouxe a Janet simbolizados pelo sucesso como escritora e também como poeta, e a possibilidade de escrever sem o controlo social que fez parte da sua vida.

Segundo Kristeva (1995), os seres humanos estão hoje em vias de perder "as suas almas", no sentido em que não cultivam qualquer tipo de lugar interior ("an inner garden"), explicando que "[t]hose who can or wish to preserve a lifestyle that downplays opulence 
as well as misery will need to create a space for an 'inner zone' - a secret garden, an intimate quarter, or more simply and ambitiously, a psychic life." (apud McAfee, 2004: 110). Podemos encontrar a importância e o cultivo desta vida interior na descrição do Envoy from Mirror City, de Janet Frame $(2010)^{11}$ e da sua imaginação, que a não deixou cair num estado de atrofiamento e de esterilidade mental de que o mundo the pareceu padecer.

\section{ANA PIRES QUINTAIS}

Aluna do curso de Doutoramento em Linguagens e Heterodoxias: História, Poética e Práticas Sociais - CES/FLUC. Licenciada em Psicologia Clínica e mestre em Psicologia Pedagógica. Atualmente encontra-se a elaborar a sua tese intitulada Literatura, Imagem e Pós-memória. Interesses principais: pós-memória, literatura, arte visual, representações da violência, Holocaust Studies.

Contacto: anaserip@gmail.com

\section{REFERÊNCIAS BIBLIOGRÁFICAS}

Douglas, Mary (1991), Pureza e perigo. Ensaio sobre as noções de poluição e tabu. Lisboa: Edições 70. Trad. Sónia Pereira da Silva [1..$^{\text {a }}$ ed.: 1966].

Frame, Janet (2010), An Angel at My Table. London: Virago Press (obras originalmente publicadas em 1982 - To the Is-Land; 1984 - An Angel at My Table; 1985 - The Envoy from Mirror City).

Freud, Sigmund (1919), Totem and Taboo. Resemblances Between the Psychic Lives of Savages and Neurotics. London: George Routledge \& Sons, Limited.

Grosz, Elizabeth (1989), Sexual Subversions. Three French Feminists. Australia: Allen \& Unwin.

Helder, Herberto (2001), "Paradiso, um pouco", Relâmpago, 9, 97-98.

Kristeva, Julia (1982), Powers of Horror. An Essay on Abjection. New York: Columbia University Press. Trad. Leon S. Roudiez [1..$^{\underline{a}}$ ed.: 1980].

McAfee, Noelle (2004), Julia Kristeva. New York/London: Routledge.

Merli, Carol; Torney, Kay (1997), "Dangerous Margins: The Body and Art in Janet Frame's Autobiographies", Women's Studies, 27, 63-83.

\footnotetext{
${ }^{11}$ Ver por exemplo pp. 520-521.
} 